\title{
New dragonflies and damselflies from Middle Miocene deposits in SW Bulgaria (Insecta: Odonata)
}

\author{
Andre Nel, Nikolay Simov, Vladimir Bozukov, and Milen Marinov
}

\begin{abstract}
The first fossil Odonata discovered in Bulgaria are described and illustrated, i.e., the aeshnid Oligaeschna bulgariensis sp. nov., the sieblosiid Stenolestes rhodopensis sp. nov., and the dysagrionid Primorilestes magnificus sp. nov. These genera are present in both Western Europe and Siberia in the Neogene. Their fossil discoveries in Bulgaria provide a link between these two regions, which are now disconnected.
\end{abstract}

Andre Nel. Institut de Systématique, Évolution, Biodiversité, ISYEB - UMR 7205 - CNRS, MNHN, UPMC, EPHE, Muséum national d'Histoire naturelle, Sorbonne Universités, 57 rue Cuvier, CP 50, Entomologie, F75005, Paris, France. anel@mnhn.fr Nikolay Simov. National Museum of Natural History, 1 Tsar Osvoboditel Blvd., 1000 Sofia, Bulgaria. myrmedobia@gmail.com Vladimir Bozukov. Institute of Biodiversity and Ecosystem Research - Bulgarian Academy of Sciences, Acad. G. Bonchev Str., 23, BG-1113 Sofia, Bulgaria.vladimir_bozukov@yahoo.com Milen Marinov. Plant Health \& Environment Laboratory, Investigation and Diagnostic Centre and Response, Ministry for Primary Industries, 231 Morrin Rd, Auckland, New Zealand. milen.marinov@mpi.govt.nz Keywords: Aeshnidae; Sieblosiidae; Dysagrionidae; new species; Miocene; Bulgaria Submission: 11 February 2016 Acceptance: 11 August 2016

\section{INTRODUCTION}

Fossil insects from Bulgaria are very scarce. Stefanoff and Jordanoff (1935) and Stefanoff and Dimitrov (1936) mentioned the presence of insects (without specifying their taxonomic affinity) in late Eocene/early Oligocene and late Miocene/Pliocene sediments. The only published fossil insect taxon from Bulgaria is a fungus gnat specimen from the region of Rashka Grashtitsa Vill. (Southwestern Bulgaria, Kyustendil Distr.), determined by Drenski as Mycetophilla (sic!) aff. pulchella Heer (Drensky and Stefanoff, 1938) with probably a late Eocene/ early Oligocene age.

zoobank.org/7FDD6614-F084-4E4F-A7CD-C6D2215CCB16

Nel, Andre, Simov, Nikolay, Bozukov, Vladimir, and Marinov, Milen. 2016. New dragonflies and damselflies from Middle Miocene deposits in SW Bulgaria (Insecta: Odonata). Palaeontologia Electronica 19.3.35A: 1-13

palaeo-electronica.org/content/2016/1593-new-dragonflies-from-bulgaria 


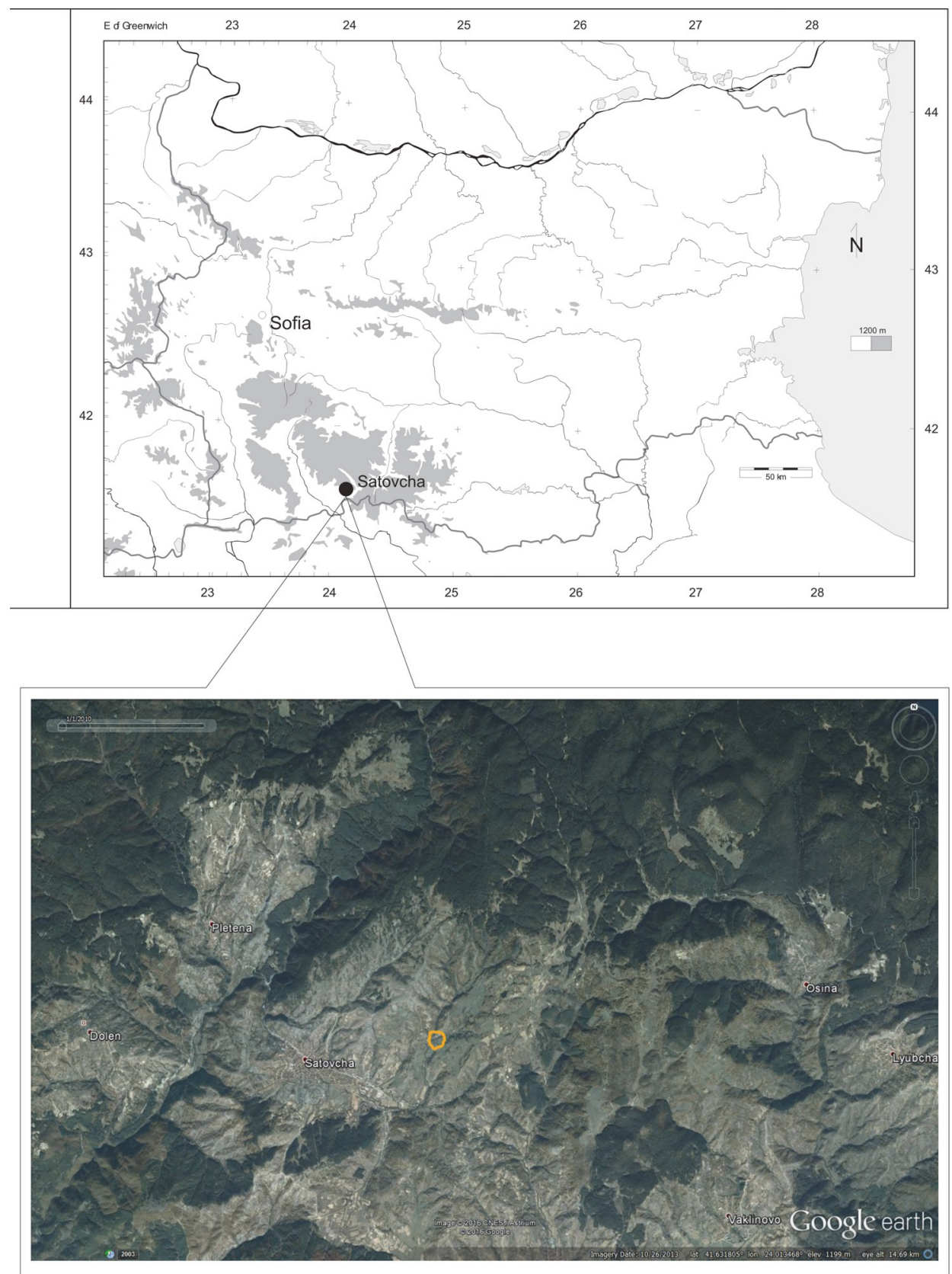

FIGURE 1. Geographic position of the study site, Satovcha Graben, SW Bulgaria. Type locality of the new species is outlined with yellow.

Here we present the first data on Miocene fossil insects from Bulgaria, which is also the first record of fossil Odonata from the country. These discoveries are of palaeobiogeographical importance because they link the Western European and the Siberian odonatan Oligocene-Miocene faunas.

\section{MATERIAL AND METHODS}

The fossil material examined for this study came from the Satovcha Graben, which is located on the southern slopes of the western Rhodopes (SW Bulgaria) and outcrops to the east from Satovcha village, in district Blagoevgrad (Figure 1). It is filled with Tertiary freshwater sedimentary and volcanic rocks. The Graben is about $7 \mathrm{~km}$ long, ca 1.5 $\mathrm{km}$ wide, and includes a total area of approximately 
$10 \mathrm{~km}^{2}$. Two official lithostratigraphic units are recognized: the Satovcha Formation and the Sivik Formation (Vatsev and Pirumova, 1983). The Sivik Formation overlies the Oligocene volcanics and sediments of the Satovcha Formation. Sedimentary rocks of the Sivik Formation lie discordantly and consist of sandstones, aleurolites, sandy clays, and diatomites with coal seams (Vatsev and Pirumova, 1983; Vatsev, 1999; Ivanov, 2013). The Sivik Formation is characterised by the presence of numerous plant fossils. It has yielded the richest palaeoflora in Bulgaria. It contains 103 fossil species as well as 28 taxa, which are close to recent plant species (Bozukov and Ivanova, 2015).

\section{Age}

There is no consensus on the exact palaeontological age of the studied strata. Jaranoff (1943) and Borisov et al. (1973) determined the age of the sediments of the Satovcha Graben as Oligocene. Vatsev and Pirumova (1983) suggested that the age of the Satovcha Formation was probably Early Oligocene. Vatsev and Pirumova (1983) identified the Sivik Formation as Middle-Late Miocene based on the diatomaceous floral composition of the sediments. Vatsev (1999) gave the age of the Sivik formation as Middle Miocene. Ognjanova-Rumenova (2003) determined the age of the top layers of the Sivik Formation through analysis of the diatom assemblages as late Miocene. Based on the total content of the macroflora from all the layers of this formation, Bozukov (2002) determined the age as Middle Miocene; this date was also confirmed by pollen analysis and is adopted here (Ivanov, 2004, 2012, 2013).

\section{Palaeoecology}

According to the analyses of the diatomaceous flora, the site corresponds to a large, deep, eutrophic freshwater palaeolake (Vatsev and Pirumova, 1983; Vatsev, 1999). The palaeolake was surrounded by mountain slopes of the rising Rhodopes, and the palaeorivers and streams deposited a flora of coenobiotic affinity. The fossil flora from the Satovcha Graben, however, is a polytopic flora, resulting from the mixing of several coexistent ecological complexes. The composition of the rich flora suggests a humid, warm-temperate to subtropical climate at this time (with annual mean temperatures above $15-16^{\circ} \mathrm{C}$, and precipitation above $1000 \mathrm{~mm}$ ) with frostless winters and the vegetation corresponding to mixed mesophytic forest, which in terms of floristic composition, is closest to "evergreen broadleaved forest" and "mixed semi-evergreen forest" of Southeast Asia (Bozukov, 2001, 2002; Ivanov, 2012, 2013). A considerable representation of thermophilic elements with wide stratigraphic range, surviving from the Palaeogene, is one of the characteristics of the Satovcha paleoflora. This confirmed the role of the Satovcha palaeoflora as a refugium for European Palaeogene relics (Bozukov, 2001, 2002, 2005; Bozukov and Ivanova, 2015) and the role of the Palaeorhodopes being a kind of a bridge used for migration across Europe, Asia and Africa (Bozukov and Ivanova, 2015).

The fossil insects reported here were discovered in the Sivik Formation. They were embedded in diatomitic clays that have been strongly compressed during diagenesis. Therefore, they are preserved as compression fossils with only minor relief. Since the fossil insects were not from the upper part of the Sivik Formation, their age should be considered as Middle Miocene.

The bulk of the fossil material and the specimens described here were collected in the period 1958-1967 during the palaeobotanical expeditions conducted by D. Jordanoff and P. Hadjiev. In the last three years of this period, E. Plamarev also joined the search.

Specimens were examined in a dry state or under ethyl-alcohol using a stereomicroscope (Zeiss Stemi 2000C) and photographed with a Panasonic Lumix DMC-FZ200 camera. All structures were measured (in $\mathrm{mm}$ ) as preserved. The fossil specimens described here are deposited in the collections of the Division of Palaeobotany and Palynology, Institute of Biodiversity and Ecosystem Research, Bulgarian Academy of Sciences.

Other insects found in the sediments in the same locality are beetles (Coleoptera), bugs (Hemiptera), caddisflies (Trichoptera), earwigs (Dermaptera), ants and bees (Hymenoptera), flies including mosquitoes, gnats and midges (Diptera), cockroaches and termites (Dictyoptera), a grasshopper and crickets (Orthoptera) (unpublished data).

\section{SYSTEMATIC PALAEONTOLOGY}

Order Odonata Fabricius, 1793

Family Aeshnidae Leach, 1815

Genus OLIGAESCHNA Piton and Théobald, 1939

Oligaeschna bulgariensis sp. nov. Figure 2

zoobank.org/3670ABBE-93C6-49EC-B5A4-1B30A6128BA3

Etymology. Named after the country of Bulgaria. 


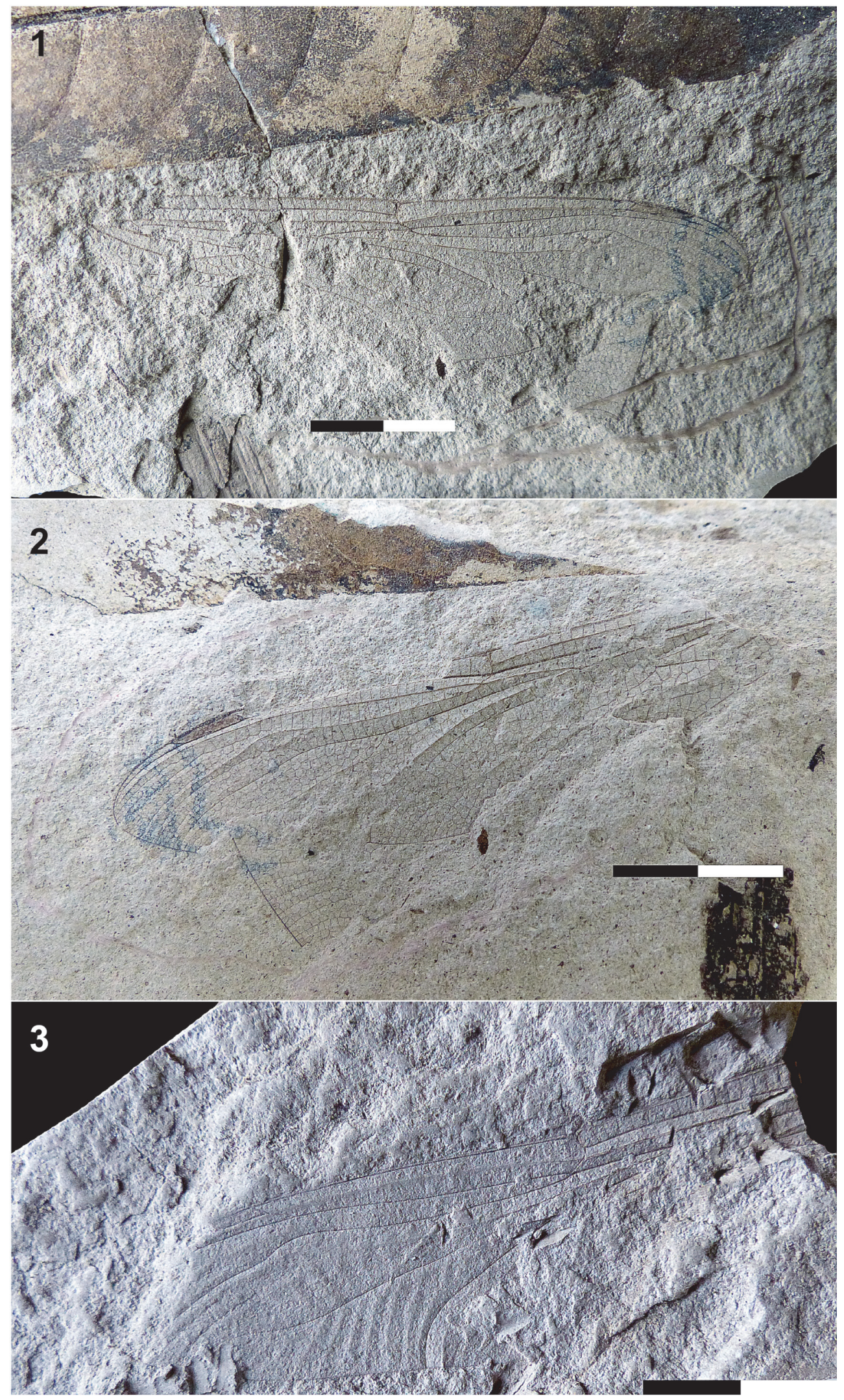

FIGURE 2. Oligaeschna bulgariensis sp. nov. 1, holotype Сат-1190a (part); 2, holotype Сат-1190b (part); 3, paratype Сат-55. Scale bars represent $5 \mathrm{~mm}$ in all figures. 
Material. Holotype Сат-1190a-b (part and counterpart, Figure 2.1-2), paratype Сат-55 (Figure 2.3). Division of Palaeobotany and Palynology, Institute of Biodiversity and Ecosystem Research, Bulgarian Academy of Sciences, Sofia, Bulgaria.

Diagnosis. Forewing venation only: pterostigmal brace long, oblique and sigmoidal; 19 postnodal crossveins; three rows of cells between IR2 and RP2.

Description. Holotype Сат-1190a-b (Figure 2.1-2). Forewing without any trace of colouration probably hyaline, preserved part $41.4 \mathrm{~mm}$ long, $10.0 \mathrm{~mm}$ wide; distance from nodus to pterostigma $14.8 \mathrm{~mm}$, pterostigma $4.5 \mathrm{~mm}$ long, $0.7 \mathrm{~mm}$ wide, covering 4 or 5 cells; pterostigmal brace elongate, distinctly oblique and sigmoidal; ca. 17 secondary antenodal crossveins distal of Ax2; 21 postnodal crossveins; hypertriangle incomplete but with crossveins; discoidal triangle elongate, transversely divided into four cells; median space free; submedian space crossed; Mspl strongly curved, five rows of cells between Mspl and MA; five Bq crossveins; oblique vein ' $O$ ' one cell distal of base of RP2; MA with slight curve opposite base of Rspl; beyond this level, two rows of cells between MA and RP3/4; Rspl strongly curved, with five rows of cells between it and IR2; IR2 unforked, with a posterior curve; four rows of cells between IR2 and RP2 in broadest part; RP2 with a distinct but smooth curved row of cells before level of pterostigma.

Paratype Сат-55 (Figure 2.3). Forewing without any trace of coloration, probably hyaline, preserved part $35.5 \mathrm{~mm}$ long, $10.5 \mathrm{~mm}$ wide; distance from nodus to pterostigma $16.5 \mathrm{~mm}$, pterostigma $4.0 \mathrm{~mm}$ long, $0.6 \mathrm{~mm}$ wide, covering 4 or 5 cells; pterostigmal brace distinctly oblique and sigmoidal; 19 postnodal crossveins; hypertriangle incomplete but with crossveins; discoidal triangle elongate; MA with slight curve opposite base of Rspl; beyond this level two rows of cells between MA and RP3/4; Rspl strongly curved, with five rows of cells between it and IR2; IR2 unforked, with a distinct posterior curve; three rows of cells between IR2 and RP2 in broadest part; RP2 with a distinct but smoothly curved row of cells before level of pterostigma.

Discussion. These two forewings can be attributed to the same species because of their nearly identical wing venation and proportions. This taxon has all the autapomorphies of the family Aeshnidae as defined by Bechly (1996), i.e., "aeshnid bulla" in distal part of MA in both pairs of wings; Rspl distinctly curved with more than one row of cells between it and IR2, and area in between divided by oblique intercalary veins; probably more than two rows of cells in basal part of postdiscoidal area between level of distal angle of discoidal triangle and level of midfork; and hypertriangle traversed by at least three crossveins. Following the study of von Ellenrieder (2002), this fossil is near Oplonaeschna de Selys-Longchamps, 1883 from the shape of the veins Rspl, IR2 and RP2. The closest modern genera differ either in the narrower area between Rspl and IR2 with less than three rows of cells, or in the forked IR2 (see Martin, 1908-1909, 1911; Fraser, 1926). This fossil differs from the recent genus Oplonaeschna in the longer pterostigma covering more than three cells. This character and the general pattern of venation fit quite well with the Cenozoic genus Oligaeschna Piton and Théobald, 1939 (revised in Nel et al., 1994). The Oligocene genus Kvacekia Prokop and Nel, 2002 is also closely related to Oligaeschna and Oplonaeschna, but it is characterized by a pterostigma covering 5 or 6 cells (4-or 5 in our fossil), and by five rows of cells in the area between IR2 and RP2 (3 in our fossil and 3 or 4 in Oligaeschna) (Prokop and Nel, 2002). Thus we propose to attribute our fossil to Oligaeschna. This genus comprises eight described species from Oligocene and Miocene deposits in North American and Eurasia. The incomplete state of preservation of our fossil renders difficult comparison with these fossils. It differs from O. kvaceki Prokop et al., 2007, O. lapidaria (Cockerell and Counts, 1913 in Cockerell, 1913), and O. saurai Peñalver et al., 1996 in the pterostigmal brace being distinctly longer and more oblique (Cockerell, 1913; Peñalver et al., 1996; Prokop et al., 2007). It shares this character with O. palaeocoerulea (Timon-David, 1946), O. ashutasica (Martynov, 1929), O. separata (Scudder, 1890), and O. jungi Piton and Théobald, 1939, from which it differs in the more numerous postnodal crossveins (19 instead of 16, 14, 13, and 12, respectively) (Scudder, 1890; Martynov, 1929; $\mathrm{Nel}$ et al., 1994). O. wedmanni Nel and Fleck, 2014 has five rows of cells between IR2 and RP2, unlike our fossil (Nel and Fleck, 2014).

Family Sieblosiidae Handlirsch, 1906

Genus STENOLESTES Scudder, 1895

Stenolestes rhodopensis sp. nov.

Figure 3

zoobank.org/553C353B-43FF-4716-A6C9-6CAEAE620423

Etymology. Named after the Rhodopes Mts. and mythical Thracian queen Rhodope.

Material. Holotype Сат-50a, Nr. Сат-50b (part and counterpart, Figure 3.1-4), paratype Сат-119 (Figure 3.5-6). Division of Palaeobotany and Palynol- 


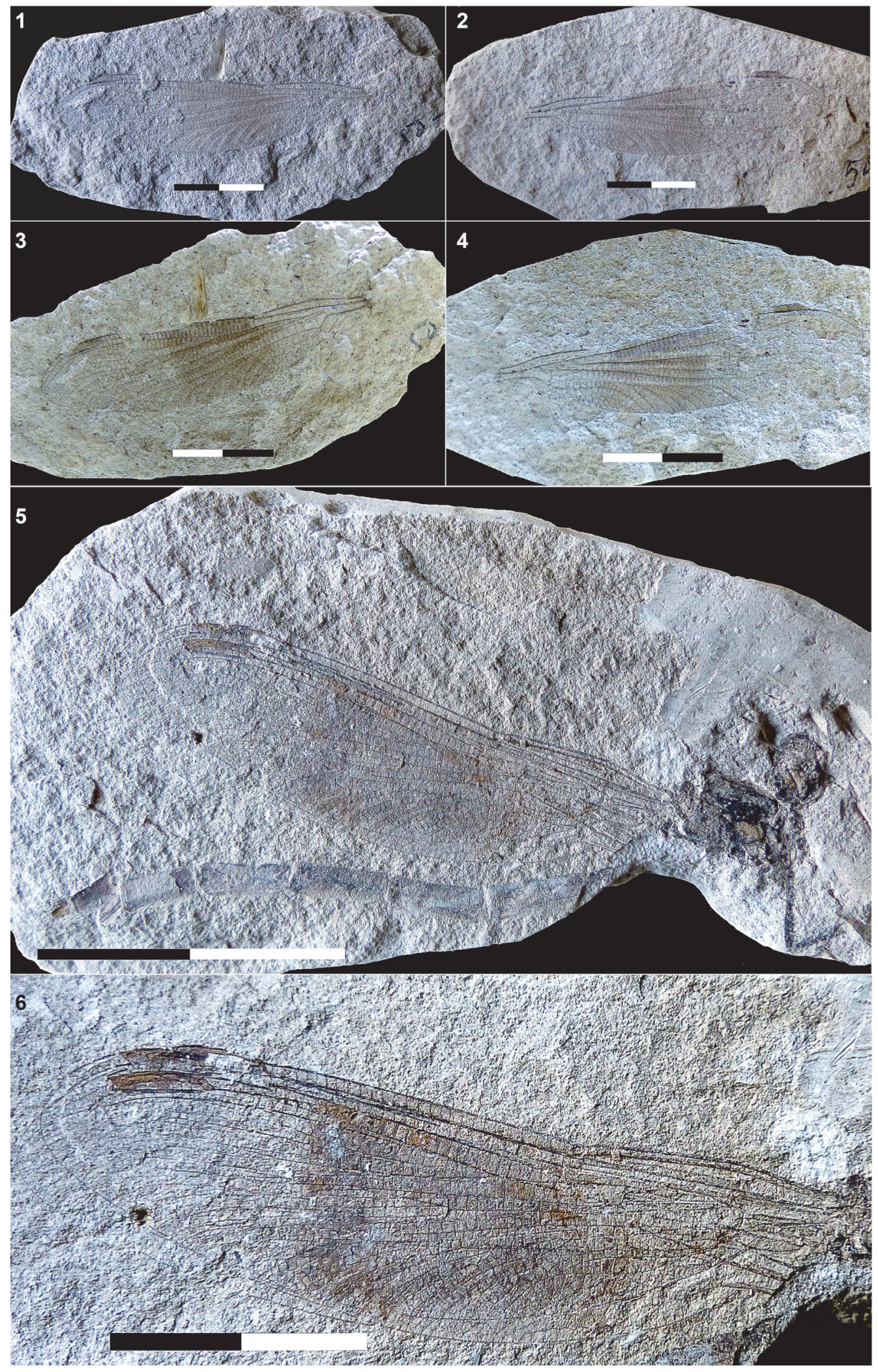

FIGURE 3. Stenolestes rhodopensis sp. nov. 1, holotype Сат-50a (part); 2, holotype Сат-50b (part); 3, 4, Сат-50a and Сат-50b - both wings; 5, paratype Сат-119 (whole insect); $\mathbf{6}$, paratype Сат-119 (wings only). Scale bars represent $5 \mathrm{~mm}$ in 1, 2, 3, 4, 6; $1 \mathrm{~cm}$ in 5 . 
ogy, Institute of Biodiversity and Ecosystem Research, Bulgarian Academy of Sciences, Sofia, Bulgaria.

Diagnosis. Wing venation only. A large median dark zone on wing; only one row of cells between RP1 and IR1 basal of pterostigma. CuA moderately long, ending on posterior wing margin slightly distal of nodus level; ca. 32-34 postnodal crossveins; one row of cells below pterostigma between RA and RP1; base of RP2 nine cells distal of subnodus; only two intercalary rows of cells between RP1 and IR1 and three between IR1 and RP2; subnodus with inverted obliquity.

Description. Wing hyaline in basal and apical thirds but with a brown band in median third; wing $34.9 \mathrm{~mm}$ long, $7.9 \mathrm{~mm}$ wide; distance from base to arculus $3.9 \mathrm{~mm}$; from arculus to nodus $7.7 \mathrm{~mm}$, from nodus to pterostigma $15.6 \mathrm{~mm}$, from pterostigma to wing apex $8.6 \mathrm{~mm}$; nodus in a basal position; pterostigma long and broad, $4.2 \mathrm{~mm}$ long, $0.8 \mathrm{~mm}$ wide, covering five or six cells; pterostigmal brace absent; only three primary antenodal crossveins $A \times 0, A \times 1$ and $A \times 2$ present, $A \times 2$ aligned with arculus, distance between $A \times 1$ and $A \times 2$ ca. $2.3 \mathrm{~mm}$; discoidal cell unicellular, $1.2 \mathrm{~mm}$ long and $1.2 \mathrm{~mm}$ wide, short and broad, broadened in its distal part, and with its distal side Mab not parallel with basal side, basal side of discoidal cell 0.45 $\mathrm{mm}$ long, anterior side $0.9 \mathrm{~mm}$ long, posterior side $1.2 \mathrm{~mm}$ long, MAb $1.2 \mathrm{~mm}$ long; ScP crossing through nodus, nodal crossvein $\mathrm{Cr}$ perpendicular to RA and subnodus Sn with a slight inverted obliquity; ca. 32-34 postnodal crossveins, not aligned with ca. 36 postsubnodal crossveins; bases of RP3/4 and IR2 between arculus and nodus, that of $\mathrm{RP} 3 / 4$ closer to arculus than to nodus, $2.5 \mathrm{~mm}$ distal of arculus, that of IR2 $3.7 \mathrm{~mm}$ distal of arculus; base of RP2 nine cells and $3.7 \mathrm{~mm}$ distal of subnodus; base of IR 1 four cells and $2.3 \mathrm{~mm}$ distally of that of RP2; oblique crossvein ' $O$ ' nine cells and $3.5 \mathrm{~mm}$ distal of base of RP2; vein CuP $0.4 \mathrm{~mm}$ distal of base of AA; cubito-anal area broad, with four rows of cells between CuA and posterior wing margin; CuA reaching posterior wing margin only $2.0 \mathrm{~mm}$ distal of nodus level; part of CuA basal of nodus level distinctly longer than part of CuA distal of nodus level; area between MP and posterior wing margin broad, with ca. eight rows of cells; postdiscoidal area narrow, $0.8 \mathrm{~mm}$ wide; area between MA and RP3/4 distally broadened; area between RP3/4 and IR2 distally broadened, with at least three rows of cells near posterior wing margin; IR2 slightly zigzagged in its distal fourth; three secondary longitudinal veins in area between IR2 and RP2; basal part of IR1 weakly zigzagged and distal part slightly curved; two secondary longitudinal veins in area between RP2 and IR1; two rows of cells in area between IR1 and RP1; one row of cells in area between RP1 and RA distal of pterostigma.

Discussion. Its shortly petiolated but large wings, ScP crossing through nodus, nodal $\mathrm{Cr}$ vertical and subnodus subvertical, bases of veins RP3/4 and IR2 midway between arculus and nodus, base of RP2 far from subnodus, show that this fossil is a sieblosiid. More precisely, this fossil can be attributed to the Sieblosiidae on the basis of the following synapomorphies (Nel et al., 2005a): "angle between MAb and MP + CuA very open," and "ScP crossing through nodus." Following the phylogenetic analysis of $\mathrm{Nel}$ et al. (2005a), this fossil can be attributed to the clade (Paraoligolestes $\mathrm{Nel}$ and Escuillié, 1993 + (Parastenolestes Nel and Paicheler, 1994 + Stenolestes Scudder, 1895)), supported by the synapomorphy "part of CuA distal of nodus level shorter than proximal part," and to the clade (Parastenolestes + Stenolestes), supported by the character state "IR1 with a strong curve." This last character is also present in Italolestes $\mathrm{Nel}$ et al., 2005b, but this last genus differs from our fossil in ScP not crossing through the nodus (see $\mathrm{Nel}$ et al., 2005a, 2005b). Our fossil differs from the genus Germanostenolestes Nel and Fleck, 2012 (a genus close to Stenolestes and Parastenolestes) in the presence of several rows of cells between RP3/4 and MA in the distal part of the wing ( Nel and Fleck, 2012). This fossil differs from Parastenolestes in the cells in the cubito-anal area not being transversely elongate ( $\mathrm{Nel}$ and Paicheler, 1994). It differs from the genus Sieblosia Handlirsch, 1906 (type species S. jucunda (Hagen, 1858)) in the curved IR1, part of CuA distal of the nodus level being shorter than the proximal part, and discoidal cell short (Nel et al., 2005a).

Within the genus Stenolestes, this fossil differs from S. adygeianensis Nel et al., 2005a in the different pattern of coloration of the wing (large apical dark zone in the latter taxon), presence of only one row of cells between RP1 and IR1 basal of the pterostigma in the former instead of two in the later. S. cerestensis $\mathrm{Nel}$ et al., 2005a has hyaline wings, short CuA reaching only the nodus level, and only 15 to 17 postnodal crossveins, unlike our fossil. S. fischeri Nel, 1986 has also a short CuA reaching only the nodus level. S. fasciata $\mathrm{Nel}$ et al., 2005a has a dark median area on its wing but in a more distal position than in our fossil, a CuA prolonged distinctly more distally than in our fossil, and two 
rows of cells below pterostigma. S. dauphinensis $\mathrm{Nel}$ et al., 1997 differs from our fossil in the base of RP2 being distinctly closer to the subnodus. S. belligaudi Nel et al., 1997 has hyaline wings, only 24 postnodal crossveins, and base of RP2 five cells distal of subnodus. S. andancensis Riou and Nel, 1995, S. hispanicus Nel, 1991, and S. camoinsi Nel, 1986 have 23 postnodal crossveins or less, unlike our fossil. S. ronzonensis (Maneval, 1936) has many more intercalary veins and cells between main veins (Nel and Paicheler, 1994). S. iris Scudder, 1895 has a straight RP2 and a broader area between RP2 and IR1 (with six rows of cells) than in our fossil (Scudder, 1895). S. coulleti Nel and Papazian, 1986 has also a broader area between RP2 and IR1, with six rows of cells, plus base of RP2 only six cells distal of subnodus ( $\mathrm{Nel}$ and Papazian, 1986; Nel and Escuillié, 1992). S. falloti (Théobald, 1937) differs from our fossil in the less numerous postnodal crossveins (ca. 28 instead of more than 30 ), vertical subnodus, and CuA ending much more distal to nodus level than in our fossil (Nel, 1986). As this fossil differs from all the other species in the genus Stenolestes, we consider that it belongs to a new species.

Family Dysagrionidae Cockerell, 1908 Genus PRIMORILESTES Nel et al., 2005c Primorilestes magnificus $\mathrm{sp}$. nov. Figure 4

zoobank.org/35068135-9682-4BF2-9534-FC5887AECACF

Etymology. Named after the fine state of preservation of the type specimen.

Material. Holotype Сат-52, Nr. Caт-53 (part and counterpart, Figure 4.1-2), paratype Сат-54 (Figure 4.3). Division of Palaeobotany and Palynology, Institute of Biodiversity and Ecosystem Research, Bulgarian Academy of Sciences, Sofia, Bulgaria.

Diagnosis. Wing venation only. Base of RP2 10 cells distal of subnodus; area between MP and posterior wing margin very broad and long; area between $\mathrm{CuA}$ and posterior wing margin broad with six secondary longitudinal veins; area between MA and RP3/4 very broad.

Description. Holotype Сат-52, Nr. Сат-53 (Figure 4.1-2). Preserved part of wing on part $26.0 \mathrm{~mm}$ long, wing ca. $32.0 \mathrm{~mm}$ long, $7.1 \mathrm{~mm}$ wide; distance from wing base to arculus $4.8 \mathrm{~mm}$, arculus to nodus $4.4 \mathrm{~mm}$, nodus to pterostigma ca. $18.0 \mathrm{~mm}$, pterostigma to wing apex $2.4 \mathrm{~mm}$; nodus in a distinctly basal position, at ca. $28 \%$ of wing length; pterostigma $2.6 \mathrm{~mm}$ long, $0.6 \mathrm{~mm}$ wide, with basal side very oblique, not parallel to distal side, covering five cells; pterostigmal brace oblique but distinctly less oblique than basal side of pterostigma; area between costa and RA distal of pterostigma with two rows of small cells, that between RA and RP1 with only one row of cells; nodal $\mathrm{Cr}$ and subnodus distinctly oblique; petiole long, $3.5 \mathrm{~mm}$ long, $1.7 \mathrm{~mm}$ wide; Ax2 opposite arculus; no secondary antenodal cross-vein distal of Ax2; no antesubnodal crossvein; 25 postnodal crossveins more or less aligned with the corresponding postsubnodal crossveins; space between arculus, base of RP3/4 and MA free; CuP distal of base of AA; AA separating from AP basal of discoidal cell; discoidal cell elongate but rather broad, $1.3 \mathrm{~mm}$ long, $0.7 \mathrm{~mm}$ wide, with its anterior and posterior sides parallel, distal side oblique, not parallel to basal side, 0.7 $\mathrm{mm}$ long; subdiscoidal space free, $1.9 \mathrm{~mm}$ long, $0.5 \mathrm{~mm}$ wide; a long cell below it between AA and posterior wing margin; base of RP3/4 near subnodus, $1.0 \mathrm{~mm}$ basal of it; base of IR2 opposite subnodus; base of RP2 10 cells distal of subnodus; base of IR1 three cells distally of that of RP2; one row of cells between RP1 and IR1; three rows and two rather long secondary longitudinal veins between IR1 and RP2, three rows between RP2 and IR2, and three rows between IR2 and RP3/4, 11 rows of cells and three long secondary longitudinal veins between RP3/4 and MA along posterior wing margin, six rows of cells and two long secondary longitudinal veins between MA and MP, area between MP and CuA very large with 20 rows of cells along posterior wing margin; four rows of cells and six secondary longitudinal veins between CuA and posterior wing margin, organized into a characteristic triadic branching pattern on $\mathrm{CuA}$; all the veins ending on posterior wing margin distinctly curved.

Paratype Сат-54 (Figure 4.3). The apical fourth of a wing, fragment $11.6 \mathrm{~mm}$ long, wing $7.5 \mathrm{~mm}$ wide; pterostigma $2.2 \mathrm{~mm}$ long, $0.7 \mathrm{~mm}$ wide, with basal side very oblique, with two postnodal crossveins ending on it, not parallel to distal side, covering five cells; pterostigmal brace oblique but distinctly less than basal side of pterostigma; area between costa and RA distal of pterostigma with two rows of small cells, that between RA and RP1 with only one row of cells; pattern of secondary longitudinal veins between main veins (IR1 to MA) identical to that of holotype.

Discussion. Although fragmentary, the paratype can be attributed to the same species as the holotype because of the exact identity of their patterns of venation in the preserved parts. It is of considerable interest because it completes the information on the pterostigma of this taxon. This fossil has very peculiar characters in that all the veins ending 


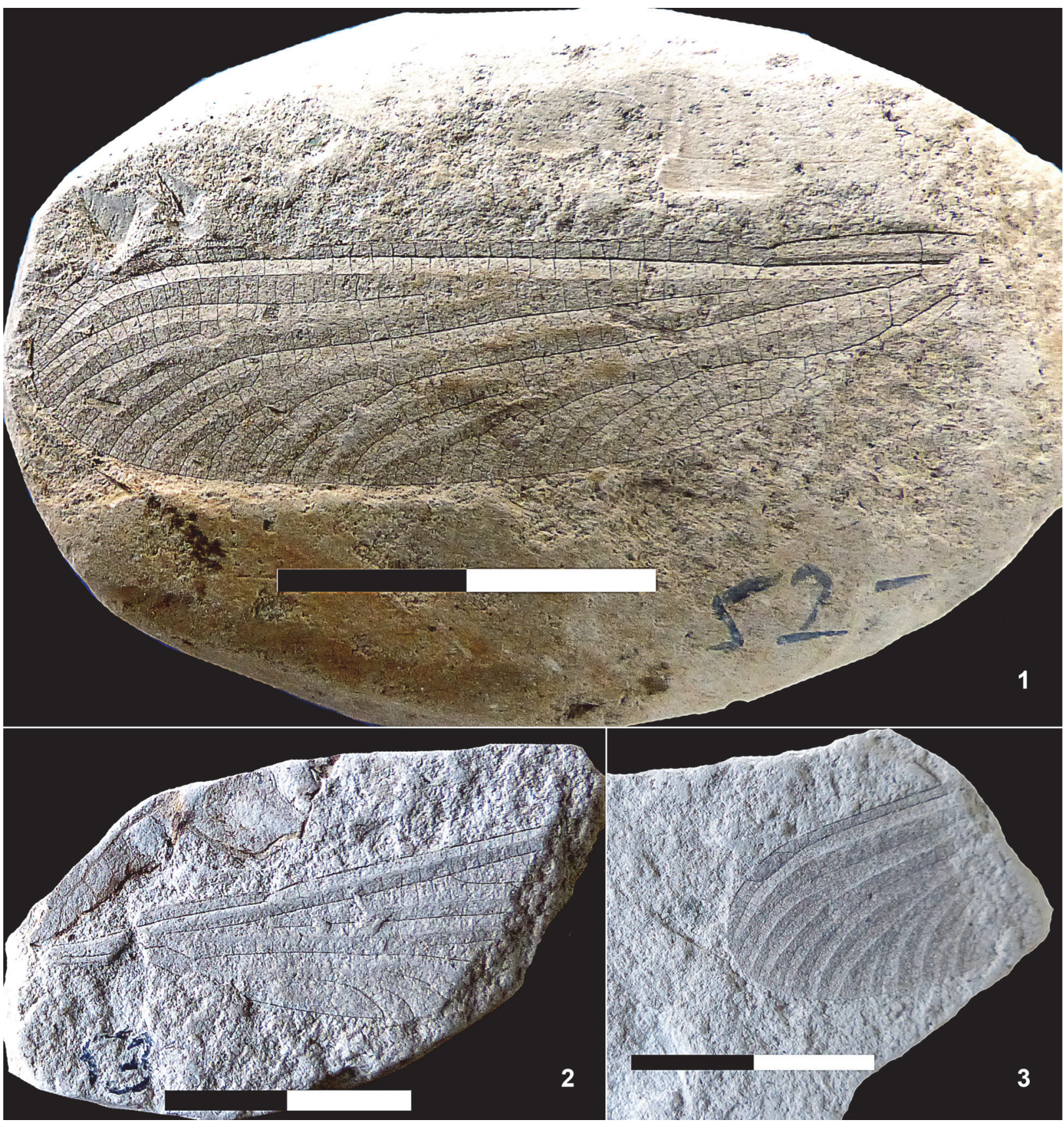

FIGURE 4. Primorilestes magnificus sp. nov. 1, holotype Сат-52 (part); 2, holotype Сat-53 (part); 3, paratype Cat-54. Scale bars represent $5 \mathrm{~mm}$ in all figures.

on the posterior wing margin are curved and there are numerous intercalary veins between nearly all the main veins, except between RP1 and IR1. Among the extant Zygoptera, only the Argiolestidae Fraser, 1957 (sensu Kalkman and Theischinger, 2013), the Pseudostigmatidae Kirby, 1890, and the Thaumatoneuridae Tillyard and Fraser, 1938 have such characters. Affinities with the Argiolestidae are excluded because they all have a reduced cubital area without the triadic branching of veins between $\mathrm{CuA}$ and the posterior wing margin. They also have AA separating from AP well distal of the basal side of the discoidal cell (Münz, 1919; Kennedy, 1925; Kalkman and Theischinger, 2013). The presence of secondary veins in the area between MP and CuA, the well-developed pterostigma, RA not strongly curved distal of the pterostigma, the presence of a cell between AA 
and the posterior wing margin below the subdiscoidal space would exclude affinities with the Pseudostigmatidae.

The Thaumatoneuridae is a small group of large damselflies that is reduced nowadays to the two Neotropical genera Thaumatoneura McLachlan, 1897, with one living species, and Paraphlebia de Selys-Longchamps, 1862 with four living species (Dijkstra et al., 2014). This group currently comprises some fossil taxa, viz. the Dysagrioninae Cockerell, 1908 (currently considered as a separate family Dysagrionidae, see Garrouste and Nel, 2015: Dysagrionini Cockerell, 1908 with the Cenozoic genera Primorilestes Nel et al., 2005c and Dysagrion Scudder, 1878; and Petrolestini Cockerell, 1927 with the Cenozoic genus Petrolestes Cockerell, 1927 and the Mesozoic genus Congqingia Zhang, 1992); the Cenozoic Eodysagrioninae Rust et al., 2008 (Eodysagrion Rust et al., 2008); and among the Thaumatoneurinae, the sole Cretaceous genus Euarchistigma Carle and Wighton, 1990 (in Euarchistigmatini Carle and Wighton, 1990) (Nel et al., 2005c; Bechly, 2007, 2016; Rust et al., 2008). Nel and Paicheler (1994) considered the Eocene Eothaumatoneura ptychoptera Pongrácz, 1935, originally attributed to the Thaumatoneuridae (Pongrácz, 1935), as Zygoptera incertae sedis.

The modern Thaumatoneuridae do not fit well with our fossil even if Primorilestes magnificus sp. nov. shares with Thaumatoneura several characters: elongate pterostigma with a basal side very oblique, two rows of cells between Costa and RA distal of pterostigma, same pattern of supplementary longitudinal veins, all veins curved at their apices on posterior wing margin, a relatively broad anal area. There are, however, also some important differences: nodus less basally recessed, distal side of discoidal cell of normal obliquity, subdiscoidal cell free; cubital area less broad. In the distal two-third of the wings, Paraphlebia shows strong similarities with $P$. magnificus, the differences between them being the narrow elongate discoidal cell of Paraphlebia and AA separating from AP below the distal side of the discoidal cell (Münz, 1919). Euarchistigma has a completely different shape of the cubital area and discoidal cell (see Bechly, 2007).

The Petrolestini Cockerell, 1927 differ from $P$. magnificus in characters described by Garrouste and $\mathrm{Nel}$ (2015), such as the broader and shorter discoidal cell and the larger and broader cubital area. In Dysagrionini Cockerell, 1908, the Ceno- zoic Dysagrion Scudder, 1878 differs from P. magnificus in the same characters.

Eodysagrion differs from $P$. magnificus in the following features given in Rust et al. (2008): distal side of the discoidal cell of inverted obliquity, longitudinal veins less curved near posterior wing margin, different shapes of the secondary veins in the cubital area; less developed area between MP and CuA.

The genus Primorilestes Nel et al., 2005c ( $P$. violetae $\mathrm{Nel}$ et al., 2005c, Early Oligocene of Primorye Territory in Russia, and P. madseni Rust et al., 2008, Earliest Eocene of Denmark) shows strong similarities with $P$. magnificus in the organization of the secondary longitudinal veins between the main veins, pterostigma, positions of the nodus and bases of the main veins, and shape of the discoidal cell. $P$. magnificus differs from $P$. madseni in the larger cubital and MP areas, and in the presence of more secondary veins in the area between MA and RP3/4. The basal half of the wing of $P$. magnificus strongly resembles that of $P$. violetae, the only difference being the base of RP2 being 10 cells distal of the subnodus in P. magnificus, while it is only six cells in $P$. violetae. Unfortunately the distal half of the wing of $P$. violetae is unknown.

Thus we propose to attribute our fossil to a new species in the genus Primorilestes.

\section{CONCLUSION}

These fossils are quite typical of the odonatan fauna of the Oligocene and Miocene of Europe. In particular Stenolestes and the whole family Sieblosiidae are strictly known from the Oligocene and the Early Miocene in Europe and Asia. The present outcrop being dated from the Middle (to Late Miocene), Stenolestes rhodopensis could be one of the youngest representative of the family Sieblosiidae. These fossils belong to three Cenozoic genera present in Western Europe and Siberia, thus it is also not surprising to discover them in the eastern part of Europe, confirming the role of the Palaeorhodopes and Balkans as a whole acting as a bridge for migration in Europe, Asia, and Africa (Markov, 2008; Bozukov and Ivanova, 2015).

The present discoveries show that the fossil odonatan paleofauna from the Sivik formation is rather diverse, comparable to that of the Oligocene of Céreste (France). Interestingly, only adults were discovered while naiads seem to be absent (or at least sufficiently rare to be unrecovered). Such situation could be surprising for rocks of lacustrine origin, but it is not unique in the Oligocene fossil record. Adult Odonata are not rare in the outcrop of 
Céreste, while absolutely no naiads have been found among 30,000 fossil insects. In the Late Oligocene outcrop of Besk Konak (Turkey), adults of Libellulidae are quite frequent while only one anisopteran naiad was discovered ( $\mathrm{Nel}$ and Paicheler, 1993). Either the naiads lived in a different place than the adults or they did not die in the place of death and fossilisation of the adults. Further studies on the taphonomic conditions of these paleolakes shall be necessary to answer to these enigmas.

\section{ACKNOWLEDGEMENTS}

We sincerely thank our friend and colleague Dr. E. Jarzembowski for his kind and efficient comments and corrections on the first version of the paper. Dr G. Markov, National Museum of Natural History, Sofia is thanked for the useful discussions on Middle Miocene records of vertebrate fauna of Bulgaria. M. Schorr, International Dragonfly Fund, provided us with very valuable suggestions and support at the beginning of the project.

\section{REFERENCES}

Bechly, G. 1996. Morphologische Untersuchungen am Flügelgeäder der rezenten Libellen und deren Stammgruppen vertreter (Insecta; Pterygota; Odonata), unter besonderer Berücksichtigung der Phylogenetischen Systematik und des Grundplanes der *Odonata. Petalura, Böblingen, Special Volume 2: 402 pp. (Revised edition of the 1995 publication, with an English appendix including a new phylogenetic system of fossil and Recent Odonata).

Bechly, G. 2007. Chapter 11.5 Odonata: damselflies and dragonflies, pp. 184-222. In Martill, D., Bechly, G., and Loveridge, R. (eds.), The Crato Fossil Beds of Brazil: Window into an Ancient World. Cambridge University Press, Cambridge.

Bechly, G. 2016. Phylogenetic systematics of Odonata. Available from: dl.dropboxusercontent.com/u/13756162/Website/ odonata/system.htm (Accessed 8 Jan. 2016)

Borisov, H., Katskov, N., and Hristanova, M. 1973. Lithology of the Tertiary sediments in Southern part of Western Rhodopes. Review of the Bulgarian Geological Society, 34(1):161-172. (In Bulgarian)

Bozukov, V. 2001. Miocene macroflora of the Satovcha Graben (Western Rhodopes). II. Paleofloristic, paleoecological and phytogeographical analysis. Phytologia Balcanica, 7(1):13-33.

Bozukov, V. 2002. Miocene macroflara of the Satovcha Graben (Western Rhodopes). III. Comparative analysis of the Satovcha paleoflora with benchmark European macrofloras. Geological age of the paleoflora. Phytologia Balcanica, 8(2):165-180.
Bozukov, V. 2005. Macclintockia basinervis (Rossm.) Knobl. in Cenozoic sediments in the Rhodopes Mt. region (S Bulgaria). Acta Palaeontologica Romaniae, 5:11-15.

Bozukov, V. and Ivanova, R. 2015. New taxonomic data on the palaeoflora from the Satovcha Graben (Southwestern Bulgaria). Comptes rendus de l'Académie Bulgare des Sciences, 68(5):623-630.

Carle, F.L. and Wighton, D.C. 1990. Chapter 3. Odonata. In: Grimaldi, D.A. (ed.). Insects from the Santana Formation, Lower Cretaceous, of Brazil. Bulletin of the American Museum of Natural History, 195:51-68.

Cockerell, T.D.A. 1908. Fossil insects from Florissant, Colorado. Bulletin of the American Museum of Natural History, 24:59-69.

Cockerell, T.D.A. 1913. Two fossil insects from Florissant with a discussion of the venation of the aeschnine dragon-flies. Proceedings of the United States National Museum, 45:577-583.

Cockerell, T.D.A. 1927. A new fossil dragonfly from the Eocene of Colorado. The Entomologist, 60:81-82.

de Selys-Longchamps, E. 1862. Synopsis des Agrionines. Troisième légion: Podagrion. Bulletin de I'Académie Royale des Sciences, des Lettres et des Beaux-Arts de Belgique, 14:5-44.

de Selys-Longchamps, E. 1883. Synopsis des Aeschnines. Premiere partie: classification. Bulletin de l'Académie Royale des Sciences, des Lettres et des Beaux-Arts de Belgique, 5:712-748.

Dijkstra, K.-D.B., Kalkman, V.J., Dow, R.A., Stokvis, F.R., and Van Tol, J. 2014. Redefining the damselfly families: a comprehensive molecular phylogeny of Zygoptera (Odonata). Systematic Entomology, 39(1):68-96.

Drensky, P. and Stefanoff, A. 1938. Das erste fossile Insekt aus Bulgarien. Mycetophilla aff. Pulchella Heer (Dipt.). Mitteilungen der Bulgarischen Entomologischen Geselltschaft in Sofia, 10:51-54.

Fabricius, J.C. 1793. Entomologia systematica emendata et aucta. Secundum classes, ordines, genera, species adjectis synonimis, locis, observationibus, descriptionibus. Tome 2. Christ. Gottl. Proft, Hafniae.

Fraser, F.C. 1926. Notes on a collection of dragonflies (Odonata) from the Dutch East Indies and descriptions of four new species from the neighbouring continent. Treubia, 8(3-4):467-494.

Fraser, F.C. 1957. A reclassification of the order Odonata, based on some new interpretations of the venation of the dragonfly wing. Handbook of the Royal Zoological Society of New South Wales, 12:1-133.

Garrouste, R. and Nel, A. 2015. New Eocene damselflies and first Cenozoic damsel-dragonfly of the isophlebiopteran lineage (Insecta: Odonata). Zootaxa, 4028(3):354-366.

Hagen, H.A. 1858. Zwei Libellen aus der Braunkohle von Sieblos. Palaeontographica, 5:121-126.

Handlirsch, A. 1906-1908. Die fossilen Insekten und die Phylogenie der rezenten Formen. Ein Handbuch für 
Paläontologen und Zoologen. Engelman, V.W. publ., Leipzig.

Ivanov, D. 2004. Pollen of some exotic plants in the Neogene of Bulgaria. Acta Palaeobotanica, 44(1):69-77.

Ivanov, D. 2012. New palynological data on some subtropical floristic elements of the Middle Miocene of Bulgaria - palaeoecological and palaeoclimatic significance, pp. 287-296. In Petrova, A. (ed.), Proceedings of the VII National Conference on Botany 2930.09.2011, Sofia, Bulgarian Botanical Society, Sofia. (In Bulgarian)

Ivanov, D. 2013. Palynological data on the Middle Miocene vegetation from Satovcha Basin, SW Bulgaria, p. 62. In Țabără D. (ed.), Ninth Romanian Symposium on Paleontology lași, 25-26 October 2013. Abstract Book. University of lași.

Jaranoff, D. 1943. Géologie des parties centrales des Rhodopes occidentales. Zeitschrift der Bulgarischen Geologischen Gesellschaft, 14(2):125-159. (In Bulgarian)

Kalkman, V.J. and Theischinger, G. 2013. Generic revision of the Argiolestidae (Odonata), with four new genera. International Journal of Odonatology, 16(1):1-52.

Kennedy, C.H. 1925. New genera of Megapodagrioninae, with notes on the subfamily. Bulletin of the Museum of Comparative Zoology, 67(7):291-311.

Kirby, W.F. 1890. A synonymic catalogue of Neuroptera Odonata, or dragonflies. With an appendix of fossil species. Gumey \& Jackson, London.

Leach, W.E. 1815. Entomology. In Brewster, D. (ed.), The Edinburgh Encyclopaedia, 9:57-172.

Maneval, H. 1936. Insectes fossiles des calcaires oligocènes de Ronzon (Le Puy). Annales de la Société Linnéenne de Lyon, 79:23-27.

Markov, G. N. 2008. Fossil proboscideans (Mammalia) from the vicinities of Varna: a rare indication of middle Miocene vertebrate fauna in Bulgaria. Historia Naturalis Bulgarica, 19:137-152.

Martin, R. 1908-1909. Aeschnines. Collections zoologiques du Baron Edm. De Selys Longchamps, Catalogue systématique et descriptif, Haye, Brussels, 18 and 19:1-84, 85-156.

Martin, R. 1911. Odonata. Fam. Aeschnidae. Subfam. Aeschninae. Genera Insectorum, 115:1-34.

Martynov, A.V. 1929. Fossil insects from Tertiary deposits in Ashutas Saisan district. Trudy Geologicheskogo Muzeya Akademii nauk SSSR, 5:173-216.

McLachlan, R. 1897. Thaumatoneura inopinata, a new genus and species of Calopteryginae. Entomologists' Monthly Magazine, 33:130-131.

Münz, P.A. 1919. A venational study of the suborder Zygoptera (Odonata) with keys for the identification of genera. Memoirs of the Entomological Society of the Academy of Natural Sciences, 3:1-78.

Nel, A. 1986. Révision du genre cénozoïque Stenolestes Scudder, 1895. Description de deux espèces nouvelles (Insecta, Odonata, Lestidae). Bulletin $d u$ Muséum National d'Histoire Naturelle, 8(4):447-461.
Nel, A. 1991. Description de quelques Sieblosiidae fossiles nouveaux (Odonata, Zygoptera, Lestoidea). Nouvelle Revue d'Entomologie, (N.S.), 8(4):367-375.

$\mathrm{Nel}, \mathrm{A}$. and Escuillié, F. 1992. Présence du genre Stenolestes Scudder, 1895 dans les laminites oligocènes du Revest-des-Brousses (Lubéron, France). L'Entomologiste, 48:337-349.

Nel, A. and Escuillié, F. 1993. Découverte d'un nouveau genre de Sieblosiidae dans le Miocène supérieur de l'Ardèche (France) (Odonata, Zygoptera, Lestoidea, Sieblosiidae). Nouvelle Revue d'Entomologie, (N.S.), 10:233-242.

Nel, A. and Fleck, G. 2012. A new genus and species of Sieblosiidae from the Middle Miocene of Germany (Odonata: Epiproctophora). Zootaxa, 3582:64-68.

Nel, A. and Fleck, G. 2014. Dragonflies and damselflies (Insecta: Odonata) from the Late Eocene of the Isle of Wight. Earth and Environmental Science, Transactions of the Royal Society of Edinburgh, 104:283306.

Nel, A. and Paicheler, J.-C. 1993. Les Libellulidae fossiles. Un inventaire critique (Odon., Anisoptera, Libelluloidea). Entomologica Gallica, 4(4):166-190.

$\mathrm{Nel}, \mathrm{A}$. and Paicheler, J.-C. 1994. Les Lestoidea (Odonata, Zygoptera) fossiles: un inventaire critique. Annales de Paléontologie, Paris, 80:1-59.

Nel, A. and Papazian, M. 1986. Sur une nouvelle espèce d'Odonate fossile du Stampien de Céreste (Lubéron) (Odonata, Lestidae). Nouvelle Revue d'Entomologie (N.S.), 3:227-233.

Nel, A., Martínez-Delclòs, X., Escuillié, F., and Brisac, P. 1994. Les Aeshnidae fossiles: état actuel des connaissances (Odonata, Anisoptera). Neues Jahrbuch für Geologie und Paläontologie, Abhandlungen, Stuttgart, 194:143-186.

Nel, A., Petrulevičius, J.F., Gentilini, G., and MartínezDelclòs, X. 2005a. Phylogenetic analysis of the Cenozoic family Sieblosiidae (Insecta: Odonata), with description of new taxa from Russia, Italy and France. Geobios, 38(2):219-233.

Nel, A., Petrulevičius, J.F., Gentilini, G., and MartinezDelclòs, X. 2005b. Un nouvel Odonate du Miocène d'Italie (Odonata). Bulletin de la Société Entomologique de France, 110(2):188.

Nel, A., Petrulevičius, J.F., and Jarzembowski, E.A. 2005c. New fossil Odonata from the European Cenozoic (Insecta: Odonata: Thaumatoneuridae, Aeshnidae, ?Idionychidae, Libellulidae). Neues Jahrbuch für Geologie und Paläontologie, Abhandlungen, Stuttgart, 235(3):343-380.

Nel, A., Martínez-Delclòs, X., Papier, F., and Oudard, J. 1997. New Tertiary fossil Odonata from France. (Sieblosiidae, Lestidae, Coenagrioniidae, Megapodagrionidae, Libellulidae). Deutsche Entomologische Zeitschrift, 44:231-258.

Ognjanova-Rumenova, N. 2003. On micropaleontology and paleoecology of Miocene nonmarine diatoms from Sivik Formation, Satovcha basin, Southwest Bulgaria. Phytologica Balcanica, 9(2):207-220. 
Peñalver, E., Nel, A., and Martínez-Delclòs, X. 1996. Insectos del Mioceno inferior de Ribesalbes (Castellón, España): Paleoptera y Neoptera Poli- y Paraneoptera. Treballs Pedagògics del Museu de Geologia de Barcelona, 5:15-95.

Piton, L. and Théobald, N. 1939. Poissons, crustacés et insectes fossiles de l'Oligocène du Puy-du-Mur, Auvergne. Mémoires de la Société Scientifique de Nancy, 4:77-123.

Pongrácz, A. 1935. Die eozäne Insektenfauna des Geiseltales. Nova Acta Leopoldina, (N.F.), 2:485-570.

Prokop, J. and Nel, A. 2002. New Tertiary dragonflies from Lower Oligocene of the České středohoři Mts and Lower Miocene of the Most Basin in the Czech Republic (Odonata: Anisoptera). Acta Societatis Zoologicae Bohemicae, 66:141-150.

Prokop, J., Přikryl, T., Dostál, O., and Nel, A. 2007. Oligaeschna kvaceki sp. nov., a new fossil dragonfly (Odonata: Aeshnidae) from the Middle Oligocene of northern Moravia (Western Carpathians). Geologica Carpathica, 58(2):181-184.

Riou, B. and Nel, A. 1995. Nouveaux Odonates fossiles du Miocène supérieur de l'Ardèche. (Odonata: Sieblosiidae, Lestidae, Libellulidae, Corduliidae, Aeshnidae). Travaux de l'Ecole Pratique des Hautes Etudes, Biologie et Evolution des Insectes, 7/8:125144.

Rust, J., Petrulevičius, J., and Nel, A. 2008. The first damselflies from the Lowermost Eocene of Denmark, with a description of a new subfamily (Odonata, Zygoptera: Dysagrionidae). Palaeontology, 51:709713.

Scudder, S.H. 1878. An account of some insects of unusual interest from the Tertiary rocks of Colorado and Wyoming. Bulletin of the United States Geological and Geographical Survey of the Territories, 4:519-543.

Scudder, S.H. 1890. The fossil insects of North America (with notes on some European species). 2. The Ter- tiary insects. Report of the United States Geological Survey of the Territories, 13:1-734.

Scudder, S.H. 1895. The Miocene insect-fauna of OEningen, Baden. Geological Magazine, 2:116-122.

Stefanoff, A. and Dimitrov, Z. 1936. Geologische Untersuchungen im Küstendiler Gebiet. Zeitschrift der Bulgarischen Geologischen Gesellschaft, 8(3):1-29. (In Bulgarian)

Stefanoff B. and Jordanov, D. 1935. Studies upon the Pliocene Flora of the Plain Sofia (Bulgaria). Sbornik na Bulgarskata Akademia na naukite, 29:3-150.

Théobald, N. 1937. Les insectes fossiles des terrains oligocènes de France. Bulletin Mensuel (Mémoires) de la Société des Sciences de Nancy, 1:1-473.

Tillyard, R.J. and Fraser, F.C. 1938. A reclassification of the order Odonata based on some new interpretations of the venation of the dragonfly wing. Part 1. The Australian Zoologist, 9:124-169.

Timon-David, J. 1946. Insectes fossiles de l'Oligocène inférieur des Camoins. 3. Description d'une nouvelle espèce d'Odonate. Bulletin de la Société Entomologique de France, 51:94-96.

Vatsev, M. and Pirumova, L. 1983. Lithostratigraphy of Tertiary sediments from the Satovcha Graben. Annuaire de l'École Supérieure des Mines et de Géologie, Sofia, 2:169-179. (In Bulgarian)

Vatsev, M. 1999. New data about stratigraphy of the Neogene rocks of the Southwestern Rhodopes, Bulgaria. Review of the Bulgarian Geological Society, 60(1-3):127-137. (In Bulgarian)

von Ellenrieder, N. 2002. A phylogenetic analysis of the extant Aeshnidae (Odonata: Anisoptera). Systematic Entomology, 27(4):437-467.

Zhang, Junfeng 1992. Congqingia rhora gen. nov., spec. nov. - a new dragonfly from the Upper Jurassic of Eastern China (Anisozygoptera, Congquingiidae fam. nov.). Odonatologica, 21:375-383. 